\title{
TSEN54 mutations cause pontocerebellar hypoplasia type 5
}

\author{
Yasmin Namavar ${ }^{1}$, David Chitayat ${ }^{2,3}$, Peter G Barth ${ }^{4}$, Fred van Ruissen ${ }^{1}$, Marit B de Wissel ${ }^{1}$, \\ Bwee Tien Poll-The ${ }^{4}$, Rachel Silver ${ }^{2}$ and Frank Baas ${ }^{\star, 1,5}$
}

Pontocerebellar hypoplasia (PCH) is a group of autosomal recessive neurodegenerative disorders characterized by prenatal onset of stunted brain growth and progressive atrophy predominantly affecting cerebellum, pons and olivary nuclei, and to a lesser extent also the cerebral cortex. Six subtypes (PCH1-6) were described and genes for four types (PCH1, 2, 4 and 6) were identified. Mutations in the tRNA splicing endonuclease subunit (TSEN) genes 54, 2 and 34 are found in PCH2 and PCH4. One family with severe prenatal onset of $\mathrm{PCH}$ has been the only representative of PCH5 published so far, and the molecular genetic status of PCH5 has not been ascertained until now. We screened the previously reported PCH5 family for mutations in the TSEN54 gene. The PCH5 patient was found to be the result of compound heterozygosity for the common TSEN54 mutation (p.A307S) plus a novel splice site mutation. The mutations associated with PCH5 are similar to what has been reported in $\mathrm{PCH} 4$. Thus, $\mathrm{PCH}$, PCH4 and $\mathrm{PCH} 2$ represent a spectrum of clinical manifestations caused by different mutations in the TSEN genes. We, therefore, propose to classify $\mathrm{PCH} 2, \mathrm{PCH} 4$ and $\mathrm{PCH} 5$ as TSEN mutation spectrum disorders.

European Journal of Human Genetics (2011) 19, 724-726; doi:10.1038/ejhg.2011.8; published online 2 February 2011

Keywords: pontocerebellar hypoplasia; PCH4; PCH5; vermal hypoplasia; TSEN54

\section{INTRODUCTION}

Pontocerebellar hypoplasias (PCHs) are a group of lethal autosomal recessive disorders characterized by prenatal onset of stunted growth and atrophy of the cerebellum, pons and olivary nuclei. Six subtypes have been identified so far, each with a distinct pathology and clinical presentation. Microcephaly and delayed development are features of all subtypes. Life expectancy is difficult to predict as survival ranges from early death ( 1 day) to adult death. ${ }^{1}$ Mutations in different genes have been identified in four of them: $\mathrm{PCH} 1, \mathrm{PCH} 2, \mathrm{PCH} 4$ and PCH6. ${ }^{1-4}$

$\mathrm{PCH} 2$ is the most common subtype and is characterized by jitteriness and the development of dyskinesia and choreatic movements. Other criteria include swallowing problems, central visual failure and the absence of primary optic atrophy. Patients usually die during childhood. Mutations in genes encoding the tRNA splicing endonuclease complex (TSEN) are responsible for $\mathrm{PCH} 2$. In most cases an alanine to serine substitution (p.A307S) in TSEN54 is found, whereas rare cases show mutations in TSEN2 and TSEN34. ${ }^{1,3,5}$

$\mathrm{PCH} 4$ presents a more severe form of $\mathrm{PCH}$ including hypertonia and severe clonus and usually more pronounced cerebellar hypoplasia (see Table 1). Nine cases of genetically confirmed PCH4 have been described so far, of which eight were compound heterozygote for a nonsense mutation or a splice site mutation and the common p.A307S missense mutation in the TSEN54 gene. ${ }^{1}$ One case carried a rare missense mutations for TSEN54 on one allele (p.S93P) in addition to homozygosity for the common p.A307S mutation. Thus, a reduced amount of, or aberrant, TSEN54 protein is present in $\mathrm{PCH} 4$ patients, resulting in a more severe phenotype in comparison with $\mathrm{PCH} 2$. In seven of eight PCH4 cases, the Magnetic Resonance Imaging (MRI) scans showed immaturity of the cerebral cortex with underdeveloped cerebral hemispheres and increased extracerebral cerebrospinal fluid volume. The cerebellar pathology in PCH4 is also more severe compared with $\mathrm{PCH} 2$. In addition to the severely affected cerebellar hemispheres, six out of eight cases showed mild or severe atrophy of the cerebellar vermis. ${ }^{1}$ In 2006 , Patel $e t ~ a l^{6}$ presented a family with a new $\mathrm{PCH}$ type identified as $\mathrm{PCH} 5$, with fetal seizures and on autopsy marked degeneration of the cerebellar vermis. The parents were healthy and non-consanguineous, with three children affected with severe olivopontocerebellar hypoplasia, two healthy siblings and a miscarriage at 12 weeks gestation. The pedigree was consistent with an autosomal recessive mode of inheritance. All affected cases suffered from intrauterine seizure-like movements, recognized by the mother as rhythmic movements and confirmed on fetal ultrasound. Patient 1 died from apnea at the age of 3 days after withdrawal of care. She suffered from generalized hypertonia, sustained clonus and respiratory distress. The pregnancies with patients 2 and 3 were terminated at 27 and 20 weeks, respectively, following the finding of clearly visible

\footnotetext{
${ }^{1}$ Department of Genome Analysis, Academic Medical Center, University of Amsterdam, Amsterdam, The Netherlands; ${ }^{2}$ The Prenatal Diagnosis and Medical Genetics Program, Department of Obstetrics and Gynecology, Mount Sinai Hospital, University of Toronto, Toronto, Ontario, Canada; ${ }^{3}$ Division of Clinical and Metabolic Genetics, Department of Pediatrics, The Hospital for Sick Children, University of Toronto, Toronto, Ontario, Canada; ‘'Division of Pediatric Neurology, Emma's Childrens Hospital, Academic Medical Center, University of Amsterdam, Amsterdam, The Netherlands; ${ }^{5}$ Department of Neurology, Academic Medical Center, University of Amsterdam, Amsterdam, The Netherlands ${ }^{*}$ Correspondence: Proffesor Dr F Baas, Department of Genome Analysis, Academic Medical Center, Meibergdreef 9, $1105 A Z$ Amsterdam, The Netherlands. Tel: +31 20566 3846; Fax +31 20566 9312; E-mail: f.baas@amc.uva.nl
}

Received 28 October 2010; revised 6 January 2011; accepted 7 January 2011; published online 2 February 2011 
Table 1 TSEN mutation spectrum and clinical manifestations

\begin{tabular}{|c|c|c|c|c|c|c|}
\hline $\begin{array}{l}\text { PCH } \\
\text { subtype }\end{array}$ & $M I M$ & $\begin{array}{l}\text { Distinguishing } \\
\text { clinical features }\end{array}$ & Lethality & Pathology of cerebellum, olivary nucleus, pons & Gene & Key references \\
\hline $\mathrm{PCH} 2$ & $\begin{array}{l}277470 \\
612389 \\
612390\end{array}$ & $\begin{array}{l}\text { Neonatal period: clonus, } \\
\text { impaired swallowing. } \\
\text { Infancy and later: chorea, } \\
\text { variable spastic pareses; } \\
\text { progressive microcephaly. } \\
\text { MRI: variable neocortical } \\
\text { atrophy, pontocerebellar } \\
\text { hypoplasia. }\end{array}$ & $\begin{array}{l}\text { Infancy and } \\
\text { childhood. } \\
\text { Adolescence } \\
\text { reached in } \\
\text { some cases }\end{array}$ & $\begin{array}{l}\text { Cerebellar hypoplasia: hemispheres } \gg \text { vermis. } \\
\text { Segmental degeneration of cortex. } \\
\text { Fragmentation of cerebellar dentate nucleus. } \\
\text { Olivary nucleus: neuron loss and decreased } \\
\text { folding. } \\
\text { Pons: progressive loss of ventral nuclei and } \\
\text { transverse fibers. }\end{array}$ & $\begin{array}{l}\text { TSEN54, p.A307S/ } \\
\text { A307S most common. } \\
\text { Rarely: Other TSEN54 } \\
\text { missense mutations. } \\
\text { TSEN2, TSEN34 } \\
\text { mutations. }\end{array}$ & $\begin{array}{l}\text { Barth et } a l^{10} \text {; Steinlin } \\
\text { et } a l^{11} \text {; Barth et } a l^{8} ; \\
\text { Budde et } a l^{3} \text {; Namavar } \\
\text { et } a l^{1}\end{array}$ \\
\hline $\mathrm{PCH} 4$ & 225753 & $\begin{array}{l}\text { Neonatal period: hypertonia, } \\
\text { severe clonus, polyhydram- } \\
\text { nios and/or contractures; } \\
\text { primary hypoventilation. } \\
\text { MRI: delayed neocortical } \\
\text { maturation, pontocerebellar } \\
\text { hypoplasia; micrencephaly } \\
\text { on autopsy. }\end{array}$ & $\begin{array}{l}\text { Early post- } \\
\text { natal death } \\
\text { from apnea }\end{array}$ & $\begin{array}{l}\text { Cerebellar hypoplasia: hemispheres } \gg \text { vermis, } \\
\text { areas of stunted or absent folial development. } \\
\text { Cerebellar dentate nucleus present as } \\
\text { tiny remnants. } \\
\text { Olivary nucleus: absent folding and gliosis. } \\
\text { Pons: loss of ventral nuclei and transverse fibers. }\end{array}$ & $\begin{array}{l}\text { TSEN54 } \\
\text { Compound heterozygos- } \\
\text { ity for p.A307S plus } \\
\text { nonsense or splice site } \\
\text { mutations. }\end{array}$ & $\begin{array}{l}\text { Albrecht et } a l^{7} ; \\
\text { Chaves-Vischer et } a l^{9} \text {; } \\
\text { Barth et } a{ }^{\beta} \text {; Budde } \\
\text { et } a l^{3} \text {; Namavar et } a l^{1}\end{array}$ \\
\hline $\mathrm{PCH} 5$ & 611523 & $\begin{array}{l}\text { Prenatal/neonatal period: } \\
\text { clonus or seizures. } \\
\text { Neonatal period: persistent } \\
\text { clonus; micrencephaly and } \\
\text { pontocerebellar hypoplasia } \\
\text { on autopsy. }\end{array}$ & $\begin{array}{l}\text { Early post- } \\
\text { natal death } \\
\text { from apnea }\end{array}$ & $\begin{array}{l}\text { Cerebellar hypoplasia: cortical involvement as in } \\
\mathrm{PCH} 4 \text {, but vermal cortex more extensively } \\
\text { affected than hemispheric cortex; subtotal loss } \\
\text { of cerebellar dentate nucleus. } \\
\text { Olivary nucleus: absent folding. } \\
\text { Pons: loss of ventral nuclei and transverse fibers. }\end{array}$ & $\begin{array}{l}\text { TSEN54 } \\
\text { Compound hetero- } \\
\text { zygosity for p.A307S } \\
\text { plus splice site } \\
\text { mutation. }\end{array}$ & Patel et $a l^{6}$, this paper \\
\hline
\end{tabular}

cerebellar hypoplasia on ultrasound. Autopsies done on these three affected cases revealed immature neurons in the pons, with gliosis and apoptosis in patients 1 and 2 and a C-shaped inferior olive present in all cases. ${ }^{6}$ The cerebellar vermis and hemispheres were severely reduced. The vermis showed absence and immaturity of Purkinje cells and distinct focal absence of the external granule cell layer. Based on the clinical and pathological manifestations, Patel et al ${ }^{6}$ proposed that this family constitute a new subtype of PCH, PCH5.

\section{METHODS}

To test whether PCH5 is part of the TSEN mutation spectrum, we tested patient 1 from the report of Patel et al ${ }^{6}$ for TSEN54 mutations with parental consent. PCR products were sequenced using the Big Dye Terminator Sequencing kit and ABI PRISM 3730XL DNA Analyser (Applied Biosystems, Foster City, CA, USA). Codon Code Software version 3.5.6 (CodonCode Corporation, Dedham, MA, USA) was used to analyse the sequenced samples.

\section{RESULTS AND DISCUSSION}

Analysis of patient 1 and his parents showed that the index case was a compound heterozygote for two TSEN54 mutations. One allele carried the common PCH-associated mutation c.919G $>$ T, p.A307S and the other a splice site mutation; c. $468+2 \mathrm{~T}>\mathrm{C}$. This variant was not found in 176 control chromosomes. Homozygosity for the p.A307S TSEN54 mutation results in $\mathrm{PCH} 2{ }^{3}$ The c. $468+2 \mathrm{~T}>\mathrm{C}$ is located in the donor splice site of intron 5, which makes skipping of exon 5 likely. This was confirmed with Alamut software, this tool uses four different splice site prediction algorithms (http://www.interactive-biosoftware.com/ alamut.html). The character of these mutations is similar to those reported in PCH4. Comparing the clinical and pathological features of
PCH5 with a genetically confirmed group of $\mathrm{PCH} 4$ patients showed that the findings are similar. ${ }^{1}$ For example, the inferior olivary nuclei in the PCH5 family reported by Patel et al ${ }^{6}$ showed a C-shaped structure similar to what is reported in $\mathrm{PCH} 4 .^{7-9}$ The absence of the external granular layer in the vermis and cerebellar hemispheres described in PCH5 is focal and similar to the segmental loss of cerebellar cortex typically seen in $\mathrm{PCH} 2$ and $\mathrm{PCH} 4 .^{8}$ In the $\mathrm{PCH} 5$ cases, the vermis was noted to be more affected than the hemispheres; however, as the vermal cortex is only relatively spared in $\mathrm{PCH} 4$ cases there is no essential difference. In our recent study, six out of eight PCH4 cases, on whom brain MRI was available, also showed mild or severe atrophy of the cerebellar vermal folia. ${ }^{1}$ The prenatal seizure-like activity observed in the PCH5 cases is similar to the severe neonatal clonus seen in PCH4. ${ }^{9}$ Although milder, the clinical findings in $\mathrm{PCH} 2$ are similar to what is reported in $\mathrm{PCH} 4$ and $\mathrm{PCH} 5 .{ }^{10}$ Early postnatal lethality due to hypoventilation, as observed in the firstborn of the PCH5 family, is also commonly observed in PCH4. ${ }^{1}$

Thus, our molecular genetic findings and the phenotype in $\mathrm{PCH} 5$ are similar to that of $\mathrm{PCH} 4$. As $\mathrm{PCH} 2$ is also caused by mutations in one of the TSEN subunits, we propose that $\mathrm{PCH} 2, \mathrm{PCH} 4$ and PCH5 will be united as a spectrum of clinical manifestations caused by different mutations in the TSEN genes (Table 1). We, therefore, propose to reassign $\mathrm{PCH} 2, \mathrm{PCH} 4$ and $\mathrm{PCH} 5$ as TSENopathies.

\section{CONFLICT OF INTEREST}

The authors declare no conflict of interest.

\section{ACKNOWLEDGEMENTS}

Financial support was kindly provided by the Hersenstichting Nederland KS2009(1)-81. 
1 Namavar Y, Barth PG, Kasher PR et al: Clinical, neuroradiological and genetic findings in pontocerebellar hypoplasia. Brain 2011; 134: 143-156.

2 Edvardson S, Shaag A, Kolesnikova 0 et al: Deleterious mutation in the mitochondrial arginyl-transfer RNA synthetase gene is associated with pontocerebellar hypoplasia. Am J Hum Genet 2007; 81: 857-862.

3 Budde BS, Namavar Y, Barth PG et al: tRNA splicing endonuclease mutations cause pontocerebellar hypoplasia. Nat Genet 2008; 40: 1113-1118.

4 Renbaum $\mathrm{P}$, Kellerman $\mathrm{E}$, Jaron $\mathrm{R}$ et al: Spinal muscular atrophy with pontocerebellar hypoplasia is caused by a mutation in the VRK1 gene. Am J Hum Genet 2009; 85: 281-289.

5 Cassandrini D, Biancheri R, Tessa A et al: Pontocerebellar hypoplasia: clinical, pathologic, and genetic studies. Neurology 2010; 75: 1459-1464.

6 Patel MS, Becker LE, Toi A, Armstrong DL, Chitayat D: Severe, fetal-onset form of olivopontocerebellar hypoplasia in three sibs: PCH type 5? Am J Med Genet A 2006; 140: 594-603.
7 Albrecht S, Schneider MC, Belmont J, Armstrong DL: Fatal infantile encephalopathy with olivopontocerebellar hypoplasia and micrencephaly. Report of three siblings. Acta Neuropathol 1993; 85: 394-399.

8 Barth PG, Aronica E, de Vries L et al: Pontocerebellar hypoplasia type 2: a neuropathological update. Acta Neuropathol 2007; 114: 373-386.

9 Chaves-Vischer V, Pizzolato GP, Hanquinet S, Maret A, Bottani A, Haenggeli CA: Early fatal pontocerebellar hypoplasia in premature twin sisters. Eur J Paediatr Neurol 2000; 4: 171-176.

10 Barth PG, Blennow G, Lenard HG et al: The syndrome of autosomal recessive pontocerebellar hypoplasia, microcephaly, and extrapyramidal dyskinesia (pontocerebellar hypoplasia type 2): compiled data from 10 pedigrees. Neurology 1995; 45: 311-317.

11 Steinlin M, Klein A, Haas-Lude $\mathrm{K}$ et al: Pontocerebellar hypoplasia type 2: variability in clinical and imaging findings. Eur J Paediatr Neurol 2007; 11: $146-152$. 